\title{
Performance versus height in Freestyle swimming in girls of 10 years
}

\author{
Ivan Wallan Tertuliano',2, Tatiana Galli Gonçalves Pinto², Caio Graco Simoni da Silva², Antonio Carlos Mansoldo², \\ Afonso Antônio Machado', Paulo Henrique Bonacella ${ }^{3}$.
}

\begin{abstract}
Introduction: The Freestyle swimming is currently known as the fastest within the competitive environment. Objective: The objective of this study was to investigate the performance differences in Freestyle swimming of female children of 10 years old, relating total time of swim and stature, in a distance of 25 meters. Method: Participated in the study 10 female children of 10 years old. The task was to swim 25 meters, as fast as possible in Freestyle swimming and, beyond this measure, was used anthropometric measure related to height. Was conducted a Pearson Correlation test. Results: The results showed that the correlation is inversely proportional (negative), weak and non-significant, in other words, swim faster has no effect on the subjects' height in the total duration of the swimming. Conclusion: The results indicate that there is no relationship between performance and height for girls of 10 years in the Freestyle swimming.
\end{abstract}

Keywords: Performance, Height and Freestyle.

\section{INTRODUCTION}

Swimming involves four different methods of swimming: Freestyle, Backstroke, Butterfly and Breastroke. Swimming demands great strength of arms and legs on a fluid surface for propulsion generation. Swimming demands different efforts between training and competition. While the swimmer can swim for several hours in the day, in training, a speed test can last a very short time, ${ }^{(1)}$ between 21 and 49 seconds, for example.

Swimming has been investigated in different perspectives since the twentieth century, in order to determine what is the most relevant aspect of the skillful swim. ${ }^{(2)}$ Most of the studies involved the Freestyle swim because it is the most practiced.

The Freestyle swimming can be understood as a complex system, since it comprises the realization of these components: action of arms, legs, trunk and breathing, in interaction. ${ }^{(3)}$

The speed in swimmers, in the competitive and in training environment, has been of great interest for the trainers and researchers. $(4,5,6,7,8)$

The study of Chollet et al. ${ }^{(4)}$ is considered a mark in the research of the Freestyle swimming, with the speed variable. In this study, the authors proposed the coordination index of the Freestyle swimming (IdC) and verified that the IdC varies according to the speed of swimming and the skill level.
The objectives of this study were to: a) describe a new tool to measure coordination between arms in IdC; b) analyze the existence or not of variations in the synchronizations between the arms, as well as, arms and legs, for different speeds and levels of performance. A total of 43 swimmers ( 29 male and 14 female), 20 years of age, were divided into three distinct skill groups. The task was to swim three times a distance of 25 meters in maximum speed, simulating, respectively, the tests of 800,100 and 50 meters. Throughout 10 meters (from 12,5 metros to 22,5 meters) the athletes were instructed to swim in apnea to not affect the IdC. To avoid the effect of fatigue there was a rest period of 2 minutes and 30 seconds between attempts. Swimmers were divided into 3 groups (high, intermediate and low skill level) according to the level of performance in the swum distances. The results showed that, for the speed referring to the distance of 800 meters, the coordination found was the sliding one for all groups. In the simulation of the tests of 100 and 50 meters, the most skilled group adopted the standard synchronization for opposition, which did not occur in the group of less skilled swimmers. Also, as the swim speed increased, because the simulated tests were shorter, the more skilled group increased the relative timing of the propulsive phases of the strokes $(40 \%)$ more than the

Corresponding Author: Ivan Wallan Tertuliano. Rua Apucarana, 220, apto 91, Bairro Tatuapé, CEP: 03311-000, São Paulo - SP. E-mail: ivanwallan@gmail.com

1 Universidade Estadual Paulista "Júlio de Mesquita Filho" (UNESP), Campus Rio Claro, Rio Claro (SP), Brazil.

${ }^{2}$ Centro Universitário Ítalo Brasileiro (UNIÍTALO), São Paulo (SP), Brazil.

Full list of author information is available at the end of the article.

Financial support: The authors declare they financed this study.

Submission date 21 April 2016; Acceptance date 14 August 2016; Publication online date 20 August 2016 
less skilled group (24\%). Finally, only the group considered high level of ability was able, with increasing speed, to decrease the relative length of the recovery phase. Together, the results indicate that these stroke changes are a feature used only by skilled swimmers to generate longer periods of propulsive force application.

In addition to speed, other variables are intensively studied, such as the effect of different variables on the stroke (eg, variant and invariant aspects in the stroke), path and the effect of breathing on the stroke of the Freestyle swimming.(2)

The aforementioned studies, together, present an advance in the knowledge about the Freestyle swimming, since, in synthesis, the results presented level of skill, speed and course as variables that influence the standard of Freestyle swimming and, consequently, the performance of the subject.

However, most of the aforementioned studies were performed in experimental situations, i.e., far from a real situation, which can lead to controversial results in the real world. Real situations of competitions present stressors factors, such as adversary, crowd, sponsor, coach, among others, that can lead to results different from those previously mentioned. Therefore, the aforementioned results cannot be generalized. Moreover, the above mentioned studies were carried out, for the most part, with adults. This fact is due to the search for answers from skilled subjects.

To be characterized as skillful, the subject must be able to present greater stability for some variables, such as swim speed, turnaround time, frequency and length of the strokes, when compared with other groups. In addition, in order for the subject to be considered skilled or expert, he needs at least 10 years of intensive practice..$^{(9)}$

However, children are already able to participate in studies, because they present spatial organization of the movements according to the technique that characterizes the Freestyle swimming, ${ }^{(10)}$ depending on the age group (between 8 and 10 years of age) do not undergo biological influences that occur in the pubertal period. ${ }^{(11)}$ Therefore, Tertuliano et al. ${ }^{(8)}$ conducted a study with the purpose of investigating the differences in speed in the Freestyle swimming of male children and to relate the results of performance with the stature of the subjects using the competitive environment (Swimming Festival of School of Physical Education and Sport of the University of São Paulo EEFE-USP). Eleven boys aged 10 years participated in the study. The task was to swim 25 meters, Freestyle swimming, as fast as possible in the competition. In addition to this measure, anthropometric measurement related to height was used. The Pearson correlation test was conducted. The results showed that the correlation is positive and moderate - swimming faster is positively correlated with the height of the children. The authors concluded that the greater stature is not determinant for a better performance in tests of Freestyle swimming for 10 years children.
Tertuliano et al. ${ }^{(8)}$ used only boys. So, will the hypothesis of Tertuliano et al. ${ }^{\left({ }^{8}\right)}$ have similar results if it is applied in female subjects with 10 years?

Thus, the objective of the present study was to investigate the differences in performance of 10-year-old female children in Freestyle swimming, relating total swimming time and height in a distance of 25 meters at a Swimming Festival of EEFE-USP.

\section{METHOD}

The study was composed of 10 female children, with 10 years old, swimming students from various schools and participants of the Swimming Festival of the School of Physical Education and Sport of the University of São Paulo (EEFE-USP). The procedures were conducted by signing the Free and Informed Consent Term (TCLE) by the responsible of the girls. The present study was approved by the Ethics and Research Commission of the Hospital and Rehabilitation Center of AACD (number: 430.624).

For this study were used tests of Freestyle swimming in the distance of 25 meters. The task was to swim as fast as possible at a given distance. All exits were marked out and timed from the beginning until their arrival in an individualized way.

The survey was conducted in the indoor and heated pool of EEFE-USP, with temperature between $27^{\circ}$ and $28^{\circ} \mathrm{C}$, according to FINA regulation. The pool used contains 25 meters long and 12.5 meters wide (semi-Olympic), with partitions to delimit its six rays.

To mark the time, in seconds, between the start and finish, CASIO chronometers were used for each swim line by series of start.

To measure height in centimeters $(\mathrm{cm})$, the equipment used was the stadiometer of the Standart da American Medical do Brasil, with marking of eighty centimeters to two meters and twenty centimeters.

The girls performed the task, swimming 25 meters in Freestyle swimming as fast as possible, starting at the deepest part of the pool $(3.60 \mathrm{~m})$ and finishing at the shallow end $(1.20 \mathrm{~m})$.

For the measures related to the task execution time, the total time of the 25-meter course in seconds was recorded by undergraduate students of the Physical Education course of EEFE-USP. The beaconing followed the model of Federação Aquática Paulista (FAP). Each starting block was monitored by an exit referee and an arrival referee. For height analysis, measurements were taken in centimeters with the subjects in a vertical position, wearing swimming suits, with backs to the collection equipment and without the use of shoes.

No differential treatment was adopted for the children, and it is important to emphasize that the girls do not train this speed (anaerobic power) in training (class), which are offered twice a week for 45 minutes and in an aerobic character. 
The collection began with the girls receiving the information about the study and soon afterwards, if they accepted to participate, their officials were invited to sign the TCLE. Then the girls' stature was measured (in centimeter). The last step of the research was to perform the task, swim 25 meters in Freestyle swimming as fast as possible.

\section{RESULTS}

Considering that all measures used are of interval nature (Table 1) and that the objective of the present study was to verify the relationship between 2 variables (total time of swimming and height), the test used was the Pearson correlation test.

Pearson correlation test expresses, in quantitative terms, the relation between two or more variables, which value may vary between $r=0.00$ and $r=1.00$, in the positive and negative direction. ${ }^{(12)}$ Values close to $r=1.00$ mean good correlation and values close to $r=0.00$ mean little correlation. The $r=1.00$ value is a signal of perfect correlation and the $r=0.00$ value is a signal of inexistent correlation.

According to the Pearson correlation test, the correlation is $r=-0.21, p=0.55, d f=10$. This means that the correlation is negative, weak and not significant - total time of Freestyle swimming has little relation to the height of the subjects (Figure 1). Based on this sample, there does not appear to be a linear relationship between total time of Freestyle swimming and height of subjects. With $r$ being negative, the presented values point to the increase of the total time of Freestyle swimming as the stature decreases. However, this relation is weak, since the value is close to $r=0.00$ (no relation).

\section{DISCUSSION}

It is a consensus among researchers that the restrictions of the individual, of a structural order, restrict movement, ${ }^{(13)}$ and this may interfere with swimming speed. Thus, the objective of this study was to investigate differences in performance of

Table 1. Measurements of the 10 subjects: Total time of swimming and height.

\begin{tabular}{ccc}
\hline Subjects & Height $(\mathbf{c m})$ & Total time of swimming (sec.) \\
\hline $\mathbf{1}$ & 124.0 & 23.12 \\
$\mathbf{2}$ & 136.0 & 22.25 \\
$\mathbf{3}$ & 123.2 & 20.66 \\
$\mathbf{4}$ & 126.4 & 25.15 \\
$\mathbf{5}$ & 126.2 & 22.75 \\
$\mathbf{6}$ & 116.2 & 27.62 \\
$\mathbf{7}$ & 122.0 & 21.40 \\
$\mathbf{8}$ & 152.8 & 24.99 \\
$\mathbf{9}$ & 132.6 & 25.07 \\
$\mathbf{1 0}$ & 117.2 & 30.53 \\
\hline
\end{tabular}

10-year-old girls, relating total time of swimming and height, at a distance of 25 meters.

In this study, assuming for statistical analysis the relationship between two variables, it was assumed that one variable may influence another variable. For this analysis, was used a statistical technique called Correlation. The function of Correlation is to determine the relationship between two or more variables, ${ }^{(12)}$ that is, how much a variable is influenced by another variable.

The results of this study showed that the correlation is inversely proportional (negative), weak and not significant - total time of Freestyle swimming has little relation with the stature of the subjects.

These results do not corroborate with the findings of Tertuliano et al., ${ }^{(8)}$ which used the same design, the same age group, the same measures, with male participants. In the aforementioned study, Pearson correlation was positive and moderate, i.e., swimming faster is positively correlated with the height of the children. The moderate correlation was that younger children are faster than older children.

In this way, the following questions can be raised: As already mentioned, are there structural differences between boys and girls that led to different results? Can other structural factors influence the results of Freestyle swimming time, such as weight, wingspan and trunk-cephalic height? Do Psychological factors influence the results of the subjects, in terms of total swimming time?

Analyzing structural differences, studies aiming anthropometric data of children and young swimmers were conducted with the purpose of verifying profile and anthropometric characteristics that interfere in the yield. $(14,15)$ This is because the attempt to standardize relevant anthropometric characteristics for swimmers, given the literature discussing the importance of anthropometric

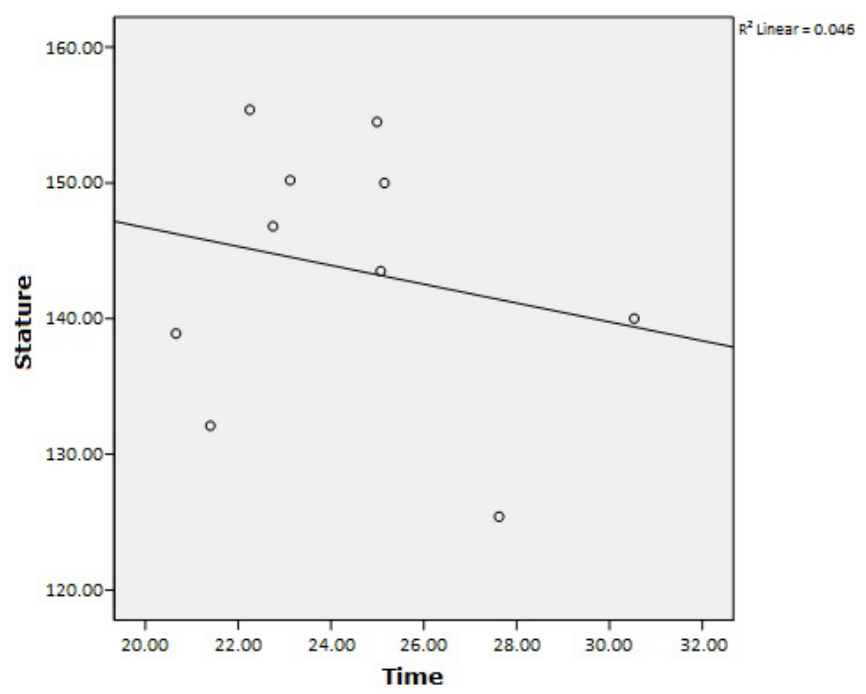

Figure 1. Relation between total time of swimming and stature of the subjects. 
characteristics in the choice of the sport by children and young people. $^{(16)}$

All of the aforementioned studies assume that swimming performance is influenced by the ability to generate propulsive force and minimize water resistance that opposes the displacement. ${ }^{(17)}$ This improvement in propulsive force can be assumed as improve of the technique, the biomechanical pattern and the physical condition of the swimmer, such as body composition and strength.

Growth and development are aspects that can be assumed to describe the changes that occur in the body and influence the generation of propulsive force.

The period of second childhood, which ranges from 6-7 years to $10-12$ years of age, is characterized by slow growth and changes in the body of a child, preceding the stretch period, which begins between 11 and 13 years of age. Children experience more development of the limbs than the trunk. The boys have higher growth of arms and legs and the girls have wider hips and thicker thighs during this period. ${ }^{(18)}$ Assuming that swimming performance is influenced by the ability to generate propulsive force and minimize water resistance that opposes displacement, ${ }^{(17)}$ It can be speculated that the fact of girls grow more in lower regions (hips and thighs) than upper regions (arms) may be directly related to the performance.

To Kjendlie, Ingjer, Stallman, and Stray-Gundersen ${ }^{(19)}$ the propulsive efficiency increases with the size of the propellant member (upper limb) and correlates with the height. However, many swimmers fail to use a technique suitable for propulsive action and thereby compromise mechanical power. ${ }^{(20,21)}$ In the present study, the correlation was weak and not significant, corroborating the findings of Vilas-Boas et al., (21) i.e., he swimmers with the best potential in terms of height were unable to use a technique suitable for propulsive action. Thus, it can be speculated that the mechanical and technical power adequate for propulsive action, have direct relation with the final result of the performance.

Tucher et al. ${ }^{(20)} \mathrm{Had}$ the objective of correlating mechanical propulsive power $(\mathrm{Pm})$ with anthropometric variables and swim time in 100 meters freestyle. Participated 42 individuals (20 girls), participants of the "Circuito Lagos de Natação-2006". The girls were between 12 and 16 years of age and $160 \pm 5.62$ $\mathrm{cm}$. The boys were between 13 and 16 years of age and 171 $\pm 8.30 \mathrm{~cm}$ The results showed, for girls, only good correlation for performance and for boys, age, manual grip strength and performance. Regarding anthropometric variables, no correlation was found with Pm. The authors assumed that the technical quality and the capacity for application and maintenance of desired force throughout the competitive event were determinant for the findings, even assuming that physical characteristics and strength-related aspects may be important for yield. The findings of Tucher et al. ${ }^{(20)}$ corroborate with the findings of the present study, since both present a weak correlation between performance and height.

The lack of technical quality of the children can be understood as lack of mastery of the mature standard of ability. This lack of mastery can be interpreted as inadequate work in early childhood toward the domain of fundamental motor skills. According to Tani et al., ${ }^{(22)}$ children should be in the phase of combining fundamental movements or as described by Gallahue et al., (18) in the phase of specialized movements. Thus, it is assumed that the child, in early childhood, should master the fundamental motor skills and, consequently, present these skills in a mature stage. ${ }^{(23)}$

Often, this does not occur, due to other variables, that are in the field of Sports Psychology. The present study was performed in a competitive environment and, as the subjects were 10 years old, the study was limited to an infant-juvenile competition. Child-juvenile competition comprises the period between 7 years and 18 years of age. Competition is a confrontation between two or more participants, aiming for a positive result, that is, the victory. ${ }^{(24)}$ There are authors who argue in favor of children's participation in competitions, such as, for example,, Gaya and Torres ${ }^{(25)}$ who consider the sport of income as an influencer in training and education, even though it is a highly selective practice. Following this line of reasoning, it can be said that the practice of sports activities is important for the formation of the child.

However, in another view, competition can be seen as a perverse aspect of the sport, as it promotes selection, individualism and, consequently, lack of equality and solidarity. ${ }^{(24)}$ Following this view, clashes between two or more participants are sources of stress. Stress is a variable considered fundamental to performance in competitions. Stress is a variable that the child must be able to handle during a competition in order to make important decisions at different moments of the event and that lead to a good result. ${ }^{(26)}$ Within the competitions, the coach and the family play a key role in stress, as they can "overcharge" the child for victory. ${ }^{\text {(27) }}$

In the present study, it can be assumed that girls with greater potential for propulsive mechanical power generation were unable to cope better with competitive stress, since they did not present the best total time of swimming and no correlation of their largest statures with a shorter total time of swimming.

When defining how the sport should be worked with the child, Ferraz ${ }^{(28)}$ suggests that two important factors are considered: readiness of the children and the optimal learning period. The first is the physical, motor, cognitive, moral and social domain to face new situations. The second concerns the periods in motor and human development that the child is in readiness (more sensitive) for new learning skills.

To Kamii ${ }^{(29)}$ the child must acquire the ability to compete and this implies that the victory is a happy outcome and that losing is part of the possibilities and consequently not 
considering this outcome as a measure of its total capacity of performance. Understanding victory and accepting defeat is not an easy task and it is up to the teacher, coach, and family to plan task-oriented strategies that involve understanding victory and accepting defeat. The importance of this knowledge goes beyond cultural and informational value, ${ }^{(22)}$ they interfere directly in the motor aspects of the skill, contributing to a better execution of the same. Therefore, respecting the child's readiness and the optimal learning period is fundamental for the proper development of interventions with the children for the understanding of victory and acceptance of defeat.

With the looks in motor learning, it can be assumed that practice is a determining factor in reaching the most advanced stages of learning and, with this, assume that the subjects who were most exposed to the practice of the task, should present the best performances. However this variable was not controlled. Even in studies with a variable of controlled experience ${ }^{(20)}$ the results corroborate those of the present study. This fact may have occurred because in the studies did not use skilled subjects.

According to Ericsson et al., ${ }^{(9)}$ to be characterized as skillful, the subject must be able to present greater stability for some variables, such as swimming speed, turnaround time, frequency and length of the strokes, when compared with other groups. In addition, in order for the subject to be considered skilled or expert, he needs at least 10 years of intensive practice. These variables were not controlled in the studies until then. Schneider and Meyer ${ }^{(15)}$ controlled the swimming time per week and the time of practice of the activity. However, its results are only of anthropometric origin, no propulsive or mechanical power test was performed. Therefore, the findings of these authors do not allow to speculate the role of the experiment in the performance results.

Based on all the explanatory hypotheses for the results, must be speculated that muscle strength, time of practice and control of the psychological factors involved in the task can be factors that influence performance. Thus, identifying the most determinant physical and psychological characteristics for success in pre-pubescent swimming is a very important step for future research, considering the variables not controlled in the present study.

\section{CONCLUSION}

Based on the results it can be concluded that height is not determinant for a better performance in Freestyle swimming tests for girls of 10 years of age. Maturity factors, physiological and psychological, such as strength, speed, weight, wingspan, trunk-cephalic height, stress, time of practice of the sport and others, may be more determinant for the best performance.

The present objective should be re-investigated, using complementary measures (strength, practice time, sexual maturation, physical maturation, size and psychological factors intervening in the competition) to relate them to the performance.

\section{AUTHOR'S CONTRIBUTIONS}

IWT, CGSS, TGGP, ACM e AAM: Elaboração do projeto de pesquisa, escrita do manuscrito e coleta de dados; IWT: Análise de dados; PGH: Coleta de dados e organização do local de coleta.

\section{CONFLICT OF INTEREST}

The authors declare that they have no conflicts of interest.

\section{AUTHOR DETAILS}

${ }^{3}$ School of Physical Education and Sport of the Universidade de São Paulo (USP), São Paulo (SP), Brazil.

\section{REFERENCES}

1. Salo D, Riewald SA. Condicionamento físico para natação. 1a ed. Barueri: Manole; 2011.

2. Apolinário MR, Oliveira TAC, Ferreira LF, Basso L, Corrêa UC, Freudenheim AM. Efeitos de diferentes padrões respiratórios no desempenho e na organização temporal das braçadas do nado "Crawl". Rev bras educ fís Esp. 2012;26(1):149-59.

3. Oliveira TAC, Apolinário MR, Freudenheim AM, Corrêa UC. Análise sistêmica do nado crawl. Braz J Mot Behav. 2009;4(1):15-21.

4. Chollet D, Chalie SS, Chatard JC. A new index of coordination for the crawl: description and usefulness. Int J Spo Med. 2000;21(1):54-9.

5. Lerda R, Cardelli C. Breathing and propelling in crawl as a function of skill and swim velocity. Int J Spo Med. 2003;24(1):75-80.

6. Seifert $L$, Chollet $D$, Rouard A. Swimming constraints and arm coordination. Hum Mov Sci. 2007;26(1):68-86.

7. Stamm A, Thiel DV, Burkett B, James DA. Towards determining absolute velocity of freestyle swimming using 3-axis accelerometers. Procedia Eng. 2011;13:120-25.

8. Tertuliano IW, Silva CGS, Mansoldo CA, Machado AA, Geraldo SM, Abreu PM, et al. Desempenho versus Estatura no Nado Crawl em crianças de 10 anos. Ter Man. 2013;11(53):295-301.

9. Ericsson KA, Krampe RT, Tesch-Romer C. The role of deliberate practice in the acquisition of expert performance. Psychol Rev. 1993;100(3):363-406.

10. Blanksby BA, Parker HE, Bradley S. Children's readiness for learning front crawl swimming. Aust J Sci Med Sport. 1995;27(2):34-7.

11. Malina RM, Bouchard C. Atividade física do atleta jovem: do crescimento à maturação. 1a ed. São Paulo: Roca; 2002.

12. Thomas JR, Nelson JK, Silverman SJ. Métodos de Pesquisa em Atividade Física. 6a ed. Porto Alegre: Artmed; 2012.

13. Haywood KM, Getchell N. Desenvolvimento Motor ao Longo da Vida. 5a ed. Porto Alegre: Artmed; 2010.

14. Prestes J, Leite RD, Leite GS, Donatto FF, Urtado CB, Bartolomeu Neto $\mathrm{J}$, et al. Características Antropométricas de jovens nadadores brasileiros do sexo masculino e feminino em diferentes categorias competitivas. Rev bras cineantropom desem hum. 2006;8(4):25-31.

15. Schneider $P$, Meyer F. Avaliação antropométrica e da força muscular em nadadores pré-púberes e púberes. Rev Bras Med Espo. 2005;11(4):209-13.

16. Damsgaard R, Bencke J, Matthiesen G, Petersen JH, Muller J. Is prepubertal growth adversely affected by sport? Med Sc. Sports Exerc. 2000;32(10):1698-703.

17. Vilas-Boas JP. A importância da depilação no rendimento desportivo em natação. Rev Port Cien Desp. 2001;1(2):65-72.

18. Gallahue DL, Ozmun JC, Goodway JC. Compreendendo o Desenvolvimento Motor: bebês, crianças, adolescentes e adultos. 7a ed. Porto Alegre: AMGH; 2013. 
19. Kjendlie PL, Ingjer F, Stallman RK, Stray-Gundersen J. Factors affecting swimming economy in children and adults. Eur J Appl Physiol. 2004;93(12):65-74.

20. Tucher G, Gomes ALM, Dantas EHM. Relação entre a potência mecânica de nado e o rendimento na natação. Rev Bras Ciênc Espo. 2009;30(2):169-80.

21. Vilas-Boas JP, Fernandes R, Kolmogorov S. Arrasto hidrodinâmico activo e potência mecânica máxima em nadadores pré-juniores de Portugal. Rev Port Cien Desp. 2001;1(3):14-21.

22. Tani G, Manoel EJ, Kokubun E, Proenca J. Educação física escolar: fundamentos para uma abordagem desenvolvimentista. 1a ed. São Paulo: EPU/EDUSP; 1988.

23. Freudenheim AM. Características complementares da criança de segunda infância e suas implicações para a educação física: Um ensaio propositivo. In: Correia WR, Basso L, editores. Pedagogia do movimento do corpo humano. Várzea Paulista: Fontoura; 2013. p. 53-65.

24. De Rose Júnior D, Korsakas P. O Processo de competição e o Ensino do Desporto. In: Tani G, Bento JO, Petersen RDS, editores. Pedagogia do Desporto. Rio de Janeiro: Guanabara Koogan; 2006. p. 251-261.
25. Gaya A, Torres L. O esporte na infância e adolescência: alguns pontos polêmicos. In: Gaya A, Marques A, Tani G, editores. Desporto para crianças e jovens: razões e finalidades. Porto Alegre: UFRGS; 2004. p. 54-74.

26. Sanches SM. A prática esportiva como uma atividade potencialmente promotora de resiliência. Rev bras psicol esporte. 2007;1(1):1-15.

27. Weis GF, Romanzini CL, Carvalho V. Competições esportivas como fonte de estresse: análise das equipes infanto-juvenis do Projeto Cestinha em Santa Cruz do Sul/RS. Rev bras cienc mov. 2011;19(1):58-65.

28. Ferraz OL. O esporte, a criança e o adolescente: consensos e divergências. In: De Rose Júnior D, editor. Esporte e atividade física na infância e adolescência: uma abordagem multidisciplinar. Porto Alegre: Artmed; 2002. p. 25-38.

29. Kamii CK. A questão da competição. In: Kamii CK, Devries RD, editores. Jogos em grupo na educação infantil: implicações da teoria de Piaget. São Paulo: Trajetória Cultural; 1991. pp. 269-285. 